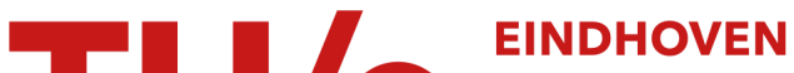 UNIVERSITY OF TECHNOLOGY
}

\section{Surface analysis of reactive ion-etched indium phosphide}

Citation for published version (APA):

Roijen, van, R., Kemp, M. B. M., Bulle-Lieuwma, C. W. T., IJzendoorn, van, L. J., \& Thijssen, T. L. G. (1991). Surface analysis of reactive ion-etched indium phosphide. Journal of Applied Physics, 70(7), 3983-3985. https://doi.org/10.1063/1.349165

DOI:

10.1063/1.349165

Document status and date:

Published: 01/01/1991

\section{Document Version:}

Publisher's PDF, also known as Version of Record (includes final page, issue and volume numbers)

\section{Please check the document version of this publication:}

- A submitted manuscript is the version of the article upon submission and before peer-review. There can be important differences between the submitted version and the official published version of record. People interested in the research are advised to contact the author for the final version of the publication, or visit the $\mathrm{DOI}$ to the publisher's website.

- The final author version and the galley proof are versions of the publication after peer review.

- The final published version features the final layout of the paper including the volume, issue and page numbers.

Link to publication

\section{General rights}

Copyright and moral rights for the publications made accessible in the public portal are retained by the authors and/or other copyright owners and it is a condition of accessing publications that users recognise and abide by the legal requirements associated with these rights.

- Users may download and print one copy of any publication from the public portal for the purpose of private study or research.

- You may not further distribute the material or use it for any profit-making activity or commercial gain

- You may freely distribute the URL identifying the publication in the public portal.

If the publication is distributed under the terms of Article 25fa of the Dutch Copyright Act, indicated by the "Taverne" license above, please follow below link for the End User Agreement:

www.tue.nl/taverne

Take down policy

If you believe that this document breaches copyright please contact us at:

openaccess@tue.nl

providing details and we will investigate your claim. 


\title{
Surface analysis of reactive ion-etched InP
}

\author{
R. van Roijen, M. B. M. Kemp, C. W. T. Bulle-Lieuwma, L. J. van ljzendoorn, \\ and T. L. G. Thijssen \\ Philips Research Laboratory, P.O. Box 80000, 5600 JA Eindhoven, The Netherlands
}

(Received 11 March 1991; accepted for publication 27 June 1991)

\begin{abstract}
A dry-etch process for InP is developed using a mixture of $\mathrm{Cl}_{2}, \mathrm{Ar}, \mathrm{CH}_{4}$, and $\mathrm{H}_{2}$. This process results in a high etch rate and good anisotropy. The induced damage is investigated by surface characterization after etching, using $x$-ray photoelectron spectroscopy, Rutherford backscattering spectrometry, photoluminescence measurements, and transmission electron microscopy. The etch mechanism is briefly discussed.
\end{abstract}

It is becoming increasingly clear that dry-etching techniques will play an important role in the fabrication of III-V devices because of the ongoing reduction of structure dimensions. ${ }^{1}$

A common objection against dry etching is that it may cause damage in the etched material. Damage can consist of structural or compositional changes, deposition of material on the surface, and diffusion into the substrate. Some reports state that damage can be found at depths of well over $10 \mathrm{~nm}$ in the material. ${ }^{2-7}$

An investigation of the damage, especially surface damage, caused by a chlorine-based etch process for InP by a range of sensitive analysis techniques is reported here: scanning electron microscopy (SEM), x-ray photoelectron spectroscopy (XPS), Rutherford backscattering spectroscopy (RBS) photoluminescence intensity measurements (PLI), and transmission electron microscopy (TEM). The etch mechanism is also briefly discussed.

At this moment a large diversity of techniques for dry etching is available, such as sputter etching, reactive-ion etching (RIE), electron cyclotron resonance (ECR) RIE, ion-beam etching (IBE), and chemically assisted IBE (CAIBE). Some of the gases used are $\mathrm{He}, \mathrm{Ar}, \mathrm{Xe}, \mathrm{Cl}_{2}$, $\mathrm{CCl}_{4}, \mathrm{CF}_{4}, \mathrm{CH}_{4}$, and $\mathrm{H}_{2}$. Several authors ${ }^{8-10}$ have proposed that RIE of InP usingCH $/ \mathrm{H}_{4}$ instead of chlorine-containing mixtures should lead to less damage, but this has not always been confirmed. ${ }^{11}$ Currently much attention is paid to etching with low ion energies, to preclude structural and/or compositional changes of the material caused by the impact of ions. Low ion energy, of the order of $100 \mathrm{eV}$, is achieved using magnetically enhanced RIE (MERIE) and ECR RIE. ${ }^{12,13}$ Some authors have reported effects at depths up to $0.3 \mu \mathrm{m} .{ }^{2-7}$ It is the purpose of this work to demonstrate that anisotropic etching of InP can be performed using a $\mathrm{Cl}_{2}$-based RIE process, with so little damage as to be acceptable for device fabrication.

$\mathrm{RIE}$, with $\mathrm{Cl}_{2}$ as the main etchant species, was carried out in an Alcatel GIR300 RIE apparatus. This is a $15-\mathrm{cm}-$ diam electrode parallel-plate machine, with the lower electrode powered at $13.56 \mathrm{MHz}$. The gases used are $\mathrm{Cl}_{2}, \mathrm{Ar}$, $\mathrm{CH}_{4}$, and $\mathrm{H}_{2}$, with flows of $4,4,4$, and $24 \mathrm{sccm}$, respectively, and the pressure is $2.5 \mathrm{~Pa}$. The quartz substrate holder is placed on the lower electrode, and is heated to $200^{\circ} \mathrm{C}$. The applied total powers are 100 and $200 \mathrm{~W}$, or 0.5 and $1.0 \mathrm{~W} / \mathrm{cm}^{2}$ corresponding to bias voltages of 480 and $770 \mathrm{~V}$, respectively. The sample surface has a temperature of approximately 215 and $240^{\circ} \mathrm{C}$ respectively.

The InP substrate material used is cleaned by etching in $\mathrm{H}_{2} \mathrm{SO}_{4}: \mathrm{H}_{2} \mathrm{O}_{2}(5: 1)$ and $\mathrm{H}_{2} \mathrm{SO}_{4}$ to remove surface contamination and oxides prior to RIE. The sample area is $2-4$ $\mathrm{cm}^{2}$. The process gives a smooth etched surface and is highly anisotropic, as can be seen from the SEM micrograph (Fig. 1). The etch rate is $0.3 \mu \mathrm{m} / \mathrm{min}$ for both 0.5 and $1.0 \mathrm{~W} / \mathrm{cm}^{2}$. It was applied successfully for the etching of laser mirrors. ${ }^{14}$ In all of the following results the surface composition was found to be homogeneous on a sample and reproducable.

An elevated temperature is necessary to evaporate the $\mathrm{InCl}_{x}$ etch products. At lower temperature $\mathrm{InCl}_{x}$ will remain on the surface and the surface becomes rough. ${ }^{15} \mathrm{We}$ have confirmed the presence of $\mathrm{InCl}_{x}$ on these rough surfaces by Auger electron spectroscopy.

First the chemical composition of the surface after RIE is determined. XPS is especially sensitive to surface contamination. XPS is performed under $90^{\circ}$ and $20^{\circ}$ electron takeoff angles, with the latter giving more information about the near-surface region. The $\mathrm{P} / \mathrm{In}$ ratio of the etched samples is very different from that of the unetched reference sample, as can be seen in Table I. Apparently the surface becomes enriched in P by RIE, and this effect increases with applied power, especially in the near-surface region detected by XPS under $20^{\circ}$ electron takeoff angle (typically $1-1.5 \mathrm{~nm}$ ).

Transfer of the samples from the etching apparatus to the XPS analysis was done under continuous nitrogen flow to prevent oxidation of the surface by air. As a result only a little oxygen can be seen in the etched samples, but the 1-nm top layer contains a substantial quantity of carbon. Since this is not due to deposition from air the carbon must have been deposited by the RIE etching process.

XPS is capable of detecting the gases $\mathrm{Cl}_{2}$ and $\mathrm{Ar}$ to below $1 \%$ atomic concentration in the top layer, so it is assumed that little $\mathrm{Ar}$ or $\mathrm{Cl}$ penetrates into the substrate or remains chemically bonded to it. Auger electron spectroscopy has also been applied, yielding the same result.

RBS, with $2-\mathrm{MeV} \mathrm{He}{ }^{+}$and a detection angle of $170^{\circ}$, has been used to study structural changes in the near-surface region. Channeling along the $\langle 100\rangle$ axis has been ap- 


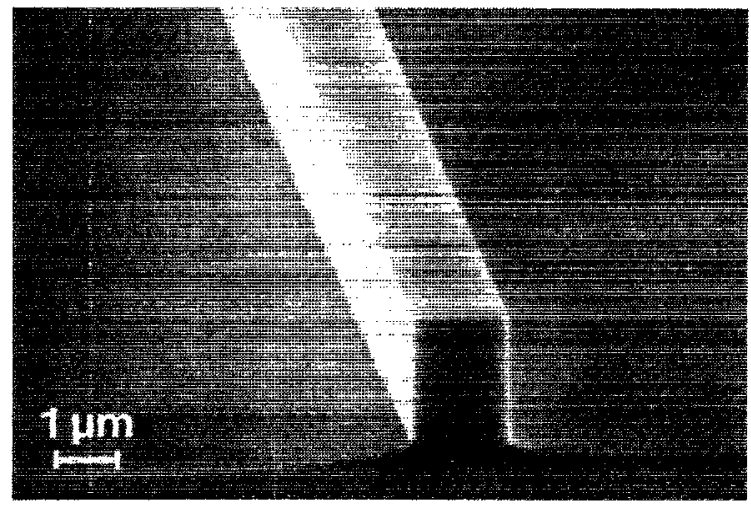

FIG. 1. SEM micrograph of a mesa and the smooth-etched surface in InP.

plied, so an increase of the yield of the In surface peak indicates an amorphous top layer. In Fig. 2 we show the result for the reference sample and the samples etched at 0.5 and $1.0 \mathrm{~W} / \mathrm{cm}^{2}$. No increase or broadening in back backscattering yield of the In surface peak was detected which implies an upper limit of approximately $4 \times 10^{15}$ $\mathrm{cm}^{-2}$ displaced In atoms in the top $15 \mathrm{~nm}$. The number of In atoms in a monolayer of InP is $7 \times 10^{14} \mathrm{~cm}^{-2}$.

High-resolution TEM micrographs of the surface, shown in Fig. 3, reveal that the surface of all substrates is covered with an amorphous layer, in apparent contradiction with the RBS results. This will be discussed below. The thickness of the layer increases with applied power. For the sample etched at $0.5 \mathrm{~W} / \mathrm{cm}^{2}$ it is $2.2 \mathrm{~nm}$ and at 1.0 $\mathrm{W} / \mathrm{cm}^{2}$ it is $4.5 \mathrm{~nm}$. The interface of the sample etched at $1.0 \mathrm{~W} / \mathrm{cm}^{2}$ is less smooth than that of the reference sample and the sample etched at $0.5 \mathrm{~W} / \mathrm{cm}^{2}$.
TABLE I. P/In ratio of the surface of an unetched reference sample, a sample etched at $0.5 \mathrm{~W} / \mathrm{cm}^{2}$, and a sample etched at $1.0 \mathrm{~W} / \mathrm{cm}^{2}$ according to XPS. Measurements are performed under $20^{\circ}$ and $90^{\circ}$ electron takeoff angles, yielding information about surface layers with a typical thickness of $1-1.5 \mathrm{~nm}$ and $3-4 \mathrm{~nm}$, respectively.

\begin{tabular}{lccc}
\hline \hline Sample & Reference & $0.5 \mathrm{~W} / \mathrm{cm}^{2}$ & $1.0 \mathrm{~W} / \mathrm{cm}^{2}$ \\
\hline $20^{\circ}$ & 0.61 & 2.1 & 2.8 \\
$90^{\circ}$ & 0.74 & 1.3 & 1.4 \\
\hline \hline
\end{tabular}

Combining the data of the TEM micrographs with those of the surface analysis it is possible to evaluate the composition of the amorphous layer. From the XPS data it seems that the layer consists mainly of phosphorus and only the topmost $1.5 \mathrm{~nm}$ is rich in carbon. The amount of carbon is independent of power.

There seems to be a contradiction between the amorphous layer revealed by TEM and the ion-channeling results, which allow only a 2-nm layer of disordered material. This can be resolved by taking into account the composition of the top layer. According to the XPS analysis the amorphous layer of the $1.0-\mathrm{W} / \mathrm{cm}^{2}$ sample contains little In to 4.0-nm depth. Since it is In and not $P$ to which RBS is most sensitive, the TEM result is not inconsistent with the ion-channeling results.. Note that in the case of $\mathrm{CH}_{4} / \mathrm{H}_{2}$ etching, the near-surface region will be enriched in In, yielding a different channeling RBS spectrum. ${ }^{11}$

The above results, especially TEM, seem to indicate that the damage of the surface after RIE is all concentrated in the amorphous top layer. This is confirmed by PLI measurements. Although it is difficult to extract quantitative results from PLI measurements ${ }^{16}$ we know that they are

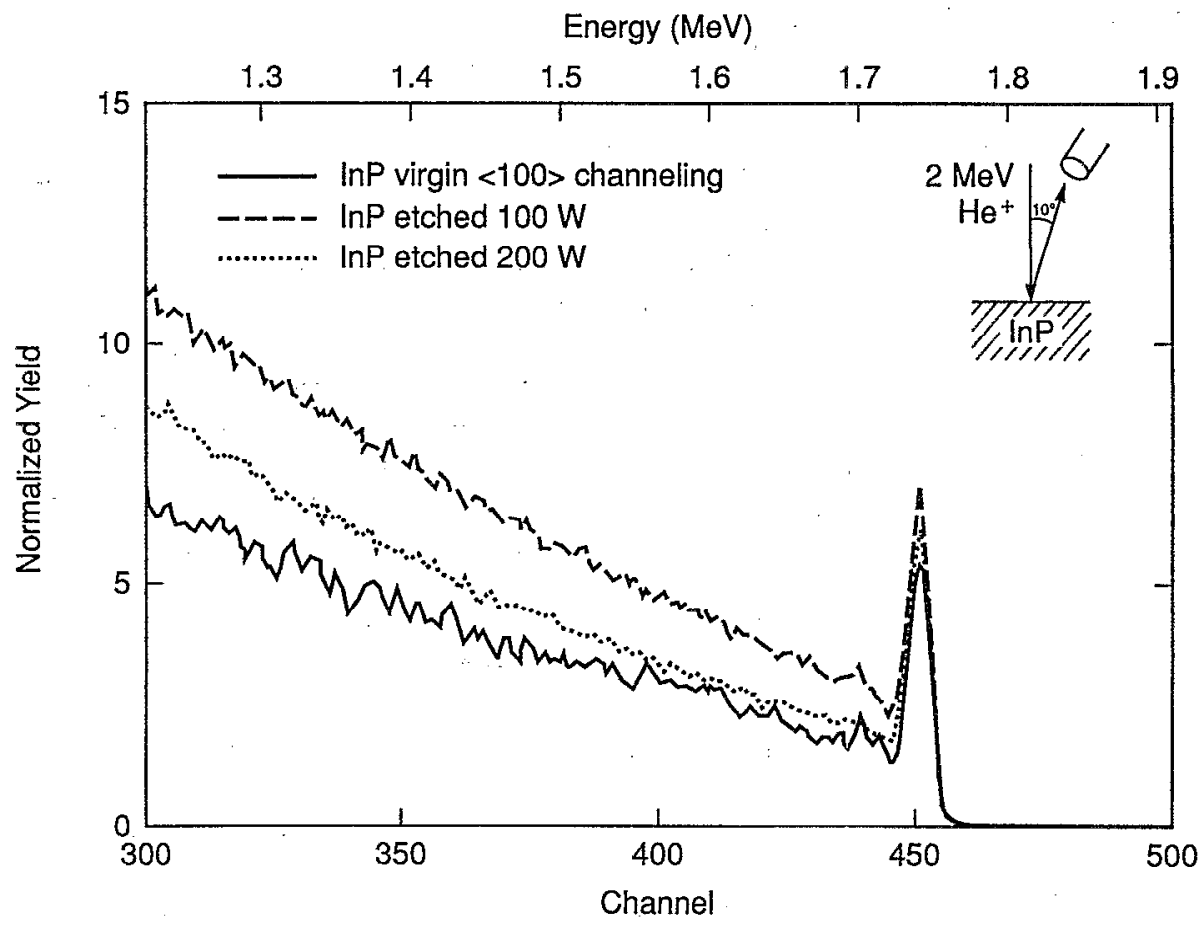

FIG. 2. Channeling RBS spectra with the ion beam aligned to the $\operatorname{InP}\langle 100\rangle$ axis, as shown in the inset. The In surface peak is not broadened after RIE at 0.5 or 1.0 $\mathrm{W} / \mathrm{cm}^{2}$. 


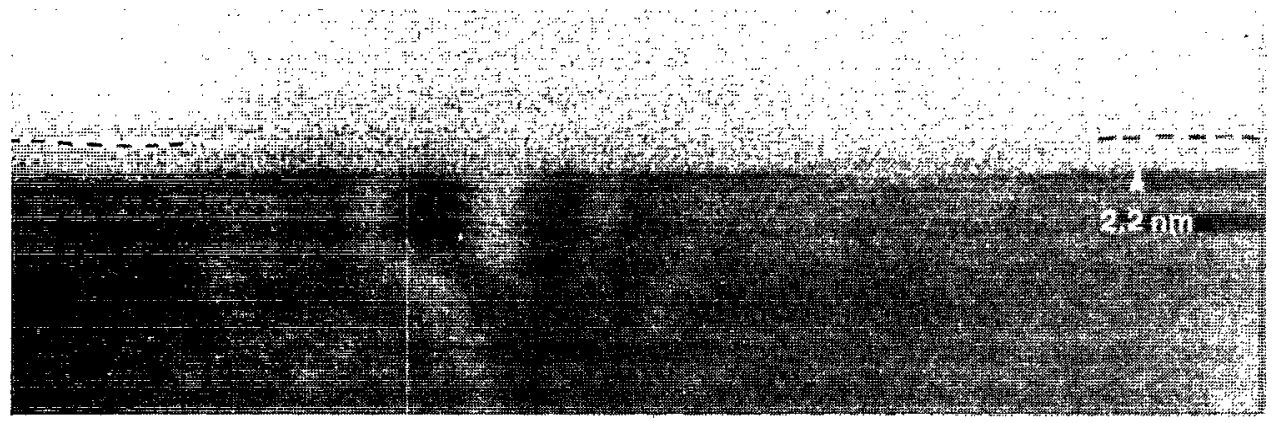

(a)

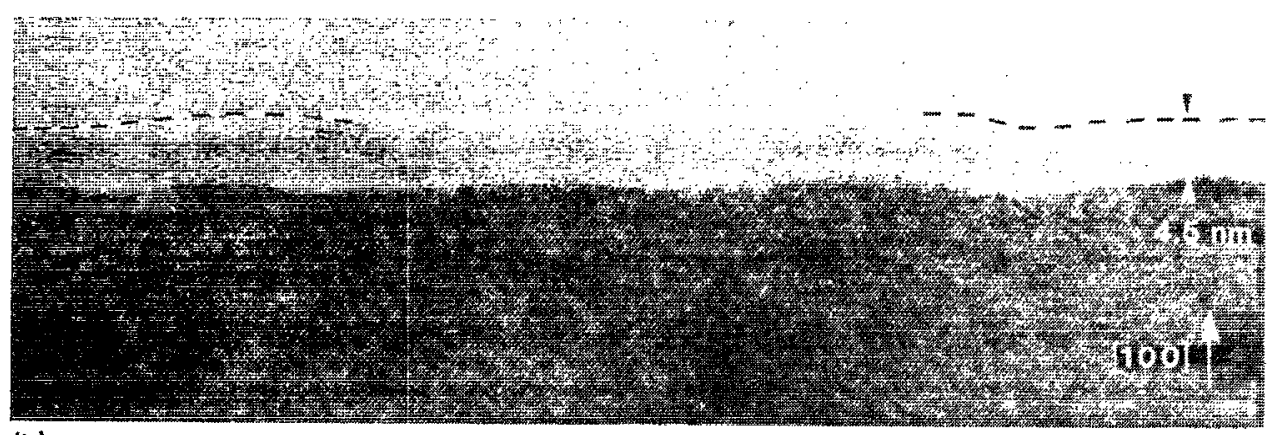

(b)
FIG. 3. High-resolution TEM micrographs of the surface of samples after etching at (a) $0.5 \mathrm{~W} / \mathrm{cm}^{2}$ and (b) 1.0 $\mathrm{W} / \mathrm{cm}^{2}$. The arrows indicate the amorphous layer thickness. extremely sensitive to damage. PLI of undoped InP samples is reduced to about 0.3 of the original signal, normalized as 1.0 , after RIE at $0.5 \mathrm{~W} / \mathrm{cm}^{2}$. After removal of 10 $\mathrm{nm}$ by anodic oxidation PLI is restored to 1.0.

To investigate deep penetration of damage we have RIE etched a layer of InP on top of a $0.1-\mu \mathrm{m}$-thick InGaAsP layer such as that used for laser fabrication. The RIE power was $0.5 \mathrm{~W} / \mathrm{cm}^{2}$ and the PLI was measured as a function of the remaining InP layer thickness. The PLI of this layer decreases only when the remaining InP on top is less than $20 \mathrm{~nm}$ thick (the resolution of the layer thickness measurement), so there is no visible damage penetrating deeper than this. The PLI data confirm that little damage is caused by the etch process and this damage is probably confined to the top $10 \mathrm{~nm}$ or less. Also double-channelplanar-buried-heterostructure lasers made by RIE perform equally well as lasers made by wet chemical etching without additional cleaning steps.

The increase of the amorphous layer thickness with power suggests a mechanism in which InP is transformed from crystalline to amorphous structure by physical impact. Comparing with a thermodynamical calculation, ${ }^{17}$ it is found that if chlorine is deficient at the surface, formation of $\mathrm{InCl}_{2}$ or $\mathrm{InCl}_{3}$ takes place. At $200^{\circ} \mathrm{C}$ the $\mathrm{InCl}_{x}$ evaporates quickly leaving a surface enriched in $\mathrm{P}$, although $\mathrm{P}$, in the form of $\mathrm{P}_{4}$, has a higher evaporation rate than $\mathrm{InCl}_{x}$. Possibly the formation of volatile $\mathrm{P}$ compounds is slower than that of $\mathrm{InCl}_{x}$. Clearly the removal of $\mathrm{P}$ is not ion enhanced, because the P-enriched layer increases and the etch rate remains equal at higher power.

In conclusion, a chlorine-based dry-etch process for InP has been developed that shows a high anisotropy and a fairly high etch rate. Straightforward thermodynamic calculation gives insight in the etching mechanism. Contrary to what is generally expected this RIE process induces very limited damage in the material and no evidence of damage at depths exceeding $10 \mathrm{~nm}$ is found. On the basis of these results we conclude that RIE of InP using a chlorine-based etch as described here is very suitable for optoelectronic applications.

${ }^{1}$ H. Beneking, J. Electrochem. Soc. 136, 2680 (1989).

${ }^{2}$ L. S. Heath, D. D. Smith, M. Dutta, M. A. Taysing-Lara, and T. P. Monahan, J. Electrochem. Soc. 136, 495 (1989).

${ }^{3}$ S. Shin, H. Chung, C. Chen, and K. Tan, J. Appl. Phys. 62, 1729 (1987).

${ }^{4}$ C. M. Knoedler, L. Osterling, and H. Shtrikman, J. Vac. Sci. Technol. B 6, 1573 (1988).

${ }^{5}$ E. L. Hu, Proceedings of the 1st International Meeting of Advanced Processing Character Technology, 1989, p. 43.

${ }^{6} \mathrm{G}$. F. Doughty, S. Thoms, R. Cheung, and C. D. W. Wilkinson, in Proceedings of the 6th International Conference on Ion and Plasma Assisted Techniques, Brighton, 1987, p. 284.

${ }^{7}$ J. Singh, J. Appl. Phys. 68, 5383 (1990).

${ }^{8}$ U. Rossow, T. Fieseler, J. Geurts, D. R. T. Zahn, W. Richter, M. S. Puttock, and K. P. Hilton, J. Phys. Condens. Matter 1, 231 (1989).

${ }^{9}$ A. J. Carter, B. Thomas, D. V. Morgan, J. K. Bhardwaj, A. M. Mcquarrie, and M. A. Stephens, IEEE Proc. 136, 2 (1989).

${ }^{10}$ T. R. Hayes, U. K. Chakkrabarti, F. A. Baiocchi, A. B. Emerson, H. S. Luftman, and W. C. Dautremont-Smith, J. Appl. Phys. 68, 785 (1990).

${ }^{11}$ S. J. Pearton, U. K. Chakrabarti, and F. A. Baiocchi, Appl. Phys. Lett. 55, 1633 (1989).

${ }^{12}$ S. J. Pearton, U. K. Chakrabarti, A. P. Kinsella, D. Johnson, and C. Constantine, Appl. Phys. Lett. 56, 1424 (1990).

${ }^{13}$ R. Cheung, Y. H. Lee, K. Y. Lee, T. P. Smith, D.P. Kern, S. P. Beaumont, and C. D. W. Wilkinson, J. Vac. Sci. Technol. B 7, 1462 (1989).

${ }^{14}$ G. J. van Gurp, J. M. Jacobs, J. J. M. Binsma, and L. F. Tiemeijer, Jpn. J. Appl. Phys. 28, L1236 (1989).

${ }^{15}$ V. M. Donnely, D. L. Flamm, C. W. Tu, and D. E. Ibbotson, J. Electrochem. Soc. 129, 2533 (1982).

${ }^{16}$ D. E. Aspnes, Surf. Sci. 132, 406 (1983).

${ }^{17}$ S. C. McNevin, J. Vac. Sci. Technol. B 4,1216 (1986). 